\title{
HIV-Infection Reduction-Rates in Patients, on Antiretroviral Efficacy-Trial of a Nigerian Broad-Spectrum Antiviral Medicine (Antivirt ${ }^{\circledR}$ )
}

\author{
M. C. O. Ezeibe1 ${ }^{*}$, B. L. Salako², F. I. O. Onyeachonam', A. David', 0. 0. Aina ${ }^{2}$, E. Herbertson², \\ M. E. Sanda' ${ }^{1}$, I. J. Ogbonna ${ }^{1}$, E. Kalu' ${ }^{1}$, N. U. Njoku${ }^{1}$, M. I. Udobi ${ }^{1}$, C. A. Akpan ${ }^{1}$ \\ ${ }^{1}$ College of Veterinary Medicine, Michael Okpara University of Agriculture, Umudike, Nigeria \\ ${ }^{2}$ Nigerian Institute of Medical Research, Lagos, Nigeria \\ Email: *maduikeezeibe@yahoo.com
}

How to cite this paper: Ezeibe, M.C.O., Salako, B.L., Onyeachonam, F.I.O., David, A., Aina, O.O., Herbertson, E., Sanda, M.E., Ogbonna, I.J., Kalu, E., Njoku, N.U., Udobi, M.I. and Akpan, C.A. (2020) HIV-Infection Reduction-Rates in Patients, On Antiretroviral Efficacy-Trial of a Nigerian BroadSpectrum Antiviral Medicine (Antivirt"). World Journal of AIDS, 10, 141-148. https://doi.org/10.4236/wja.2020.102012

Received: June 8, 2020

Accepted: June 27, 2020

Published: June 30, 2020

Copyright ( 2020 by author(s) and Scientific Research Publishing Inc. This work is licensed under the Creative Commons Attribution International License (CC BY 4.0).

http://creativecommons.org/licenses/by/4.0/

\section{(c) (i) Open Access}

\begin{abstract}
In verifying antiretroviral efficacy of a Nigerian broad spectrum antiviral medicine (Antivirt ${ }^{\circledR}$ ), the Nigerian Institute of Medical Research certified it safe by toxicological test on laboratory animals, before commencing treatment of three HIV/AIDS patients whose viral loads varied widely (millions, hundreds of thousands and thousands). To overcome errors associated with such wide differences in subject-classes, percentages of viral load-reductions were calculated instead of comparing their viral loads. After first month of the Antivirt ${ }^{\circledR}$-treatment, means of ranked viral loads of the patients significantly $(\mathrm{P} \leq 0.05)$ increased from $10.00 \pm 7.21$ to $11.30 \pm 5.51(-41.03 \%$ infection-reduction rate) instead of reducing. From second month of the trial, their viral loads started to reduce, continuously, so that their infection-reduction rates have been increasing from that $-41.03 \%$, to $-38.22 \%$ in the second month; $23.98 \%$ in the third month; $31.76 \%$ in the fourth month and $64.12 \%$ after the fifth month.
\end{abstract}

\section{Keywords}

Antivirt $^{\circledR}$, Opposite Charges' Electrostatic Attraction, Continuous Depletion Of HIV-Infection Loads

\section{Introduction}

Immune deficiency means deficit of blood lymphocytes [1]. It is not a clinical abnormality but predisposes to secondary infections which cause clinical abnormalities. When individuals or animals that were born with normal blood 
lymphocytes-counts, develop significantly low lymphocytes-counts the condition is termed acquired immune deficiency syndrome (AIDS). Most cases of AIDS in mammals are caused by Lentiviruses [2], a genus of single stranded RNA viruses of the family Retroviridae. Lentivirus that causes AIDS in humans is the Human immune deficiency virus (HIV) while in the nonhuman primates, AIDS is caused by Simian immune deficiency virus (SIV). Lentiviruses that cause AIDS, have also been isolated from horses, cattle, sheep and cats.

Special effort is required in developing antiviral medicines to work under state of immune-deficiency because small sizes of viruses enable them infect cells which are inaccessible to medicines of large molecules. So, antiviral medicines that act by physical effects need immunity for complementation while side effects of medicines that act against biochemistry of viruses become intolerable to patients when treatments continue for a long time (viral and animal cells-biochemistry are similar).

Under state of immune deficiency, infections in cells that are inaccessible to medicines cannot be cleared. For that reason, such cells are called "viral reservoirs" or "sanctuary cells". So, antiretroviral medicines (ARVs) should be targeted against physical activities of HIV instead of its biochemistry (to minimize side effects) while their molecules should be smaller than the virus so that they can reach all infected cells. Otherwise, they cannot terminate HIV-infections (cure HIV/AIDS).

That electrostatic attraction would make electrically charged medicines mop pathogens of opposite electrical charges is an old scientific knowledge and that viruses and abnormal (infected/tumor) cells are electrically charged [3] [4] has been discovered. That most epidemics/epizootics, including HIV/AIDS, Ebola, Lassa fever, Covid-19, viral hepatitis and Avian Influenza are viral diseases, is already known.

Molecules of Aluminum-magnesium silicate (AMS), an already approved medicine/pharmaceutical stabilizing agent, consist of Nanoparticles [5] that are only $0.96 \mathrm{~nm}$ thick [6]. The AMS-Nanoparticles are smaller than any known virus $(\geq 5 \mathrm{~nm})$. They have negative and positive electrically charged ends [6] but unlike abnormal cells, healthy cells are neutral (bio-medical marker). The charges enable AMS mop/destroy viruses/abnormal cells, by opposite charges-electrostatic attraction. As a silicate, AMS also normalizes immunity [7] and as a stabilizing agent [6] it enhances efficacy of antimicrobial agents for effective treatment of secondary infections.

AMS is not one of the minerals found in Nigeria but the country has large deposits of Aluminum silicate $\left(\mathrm{Al}_{4}\left(\mathrm{SiO}_{4}\right)_{3}\right)$ and Magnesium silicate $\left(\mathrm{Mg}_{2} \mathrm{SiO}_{4}\right)$. These solid minerals were used for a reaction [8] to get the Medicinal synthetic AMS \{MSAMS; Antivirt $\left.{ }^{\circledR}: \mathrm{Al}_{4}\left(\mathrm{SiO}_{4}\right)_{3}+3 \mathrm{Mg}_{2} \mathrm{SiO}_{4} \rightarrow 2 \mathrm{Al}_{2} \mathrm{Mg}_{3}\left(\mathrm{SiO}_{4}\right)_{3}\right\}$. Dextrose monohydrate (simple sugar) was formulated with the MSAMS, to convey the charged particles across mucous membranes [9], into blood, by active-transport. Mopping viruses; Destroying abnormal cells; Normalizing immunity; Effective 
treatment of secondary infections, would cure any viral/abnormal-cell disease including, HIV/AIDS, Lassa fever and Covid-19.

The Nigerian Antivirt ${ }^{\circledR}$ mops viruses by opposite charges electrostatic attraction. So, we are introducing opposite charges electrostatic attraction between medicines and pathogens as a mechanism of action for terminating infections of electrically charged agents including HIV and other viruses. We are also applying the principle of active transport to convey AMS (which is un-absorbable) into blood-circulation so that it functions as a systemic medicine. Ability of AMS to enhance efficacy of antimicrobial agents [10] so that secondary infections are effectively treated also helps in treating viral diseases.

With enhanced efficacy, lower doses achieve desired effects. Use of lower doses for treatments minimizes side effects of medicines. When side effects are minimized, immune responses of patients improve. Enhancing efficacy of antimicrobial agents and improving immune responses of patients lead to cure of even Antimicrobial Resistant Infections thus increasing chances of patients of viral diseases including HIV/AIDS to recover.

Reason existing ARVs do not achieve permanent cure of HIV/AIDS is that their molecules are too large to cross physiological barriers. For that limitation, they do not reach HIV infections "hidden" in some cells. So, even when viral loads in blood of patients they are used to treat become undetectable, the infection may still remain "hidden". Since the Antivirt ${ }^{\circledR}$ is made of ultra-Nanoparticles, it crosses physiological barriers and reaches HIV and HIV-infected cells in every organ/tissue. And since it acts by a physical effect, it is safe for any treatment-duration needed to terminate any HIV-infection.

\section{Materials and Methods}

Nigerian Institute of Medical Research (NIMR), certified the Antivirt ${ }^{\circledR}$ toxicologically safe by testing it on mice before recruiting three HIV/AIDS volunteers (all adults), for phase one clinical trial of the medicine, patented as broad spectrum antiviral medicine and antiretroviral medicine [11]. A formulation of the MSAMS and Ampicillin trihydrate (Antivirt $\mathrm{A}^{\circledR}$ ) and a formulation of the MSAMS alone (Antivirt $\mathrm{B}^{\circledR}$ ) were submitted by the inventor for treatment of the patients which started in December 2019 and has so far lasted till May 2020. The patients were placed on oral medication with Antivirt ${ }^{\circledR}$ A for 30 days, at dose rates of $50 \mathrm{mg}$ of the MSAMS/ $\mathrm{kg}$ body weight and $7.5 \mathrm{mg}$ of MSAMS-stabilized Ampicillin trihydrate/kg body weight, daily. After the first 30 days, they are now on Antivirt ${ }^{\circledR}$ B at dose of $50 \mathrm{mg} / \mathrm{kg}$. They will continue on the Antivirt ${ }^{\circledR}$ B treatment till they test HIV-antigen negative. Each patient is also on Immunace extra protection $^{\circledR}$ (Vitabiotics, England), as source of antioxidants, at the rate of one tablet, everyday. The Antivirt ${ }^{\circledR}$ is taken at night, at least two hours after dinner (empty stomach) and the patients are asked to eat no other thing (except water) once they have taken the Antivirt ${ }^{\circledR}$ till the following morning. The Immunace extra-protection ${ }^{\circledR}$ is taken in the morning, immediately after meal (full stomach). If a patient needs to take any other oral medicine for any reason, such 
other medicine is taken at least two hours before the Antivirt ${ }^{\circledR}$ or two hours after. Viral loads of the patients are tested for, every month. Their recovery rates are also assessed by their doctors, every month. Viral loads of the patients in first five months of the trial have been ranked and their means compared by the Kruskal wallis Analysis of Variance statistical method. Percentage by which each patient's viral load reduces every month (based on his/her baseline viral load) is also being calculated and used to assess antiretroviral efficacy of the Antivirt ${ }^{\circledR}$.

\section{Results}

After one month of treatment with the Antivirt ${ }^{\circledR}$, symptoms cleared from the patients and they have remained stable. Means of their viral loads (ranked) increased $(P \leq 0.05)$ from $10.00 \pm 7.21$ to $11.30 \pm 5.51$ in the first month before decreasing $(\mathrm{P} \geq 0.05)$ to $10.67 \pm 6.81$ (in the second month), $8.67 \pm 5.68$ ( $\mathrm{P} \leq$ 0.05: in the third month), $9.00 \pm 5.57$ (P $\leq 0.05$ : in the fourth month) and $7.33 \pm$ 6.03 ( $\mathrm{P} \leq 0.05$ : in the fifth month): Table 1 . Their viral load-reduction rates decreased from 00.00 to $-41.03 \%$ in the first month before increasing to $-38.22 \%$ (in the second month), 23.98\% (in the third month), 31.76\% (in the fourth month) and $64.12 \%$ (in the fifth month): Table 2 . The viral loads (as reported by NIMR) which were used for the ranking are as on Table 3.

\section{Discussion}

Increase in viral loads of HIV/ADS patients treated with the Antivirt ${ }^{\circledR}$ in first

Table 1. Monthly Ranked viral loads of HIV/AIDS patients being treated with the Nigerian Antivirt ${ }^{\circledR}$

\begin{tabular}{ccccccc}
\hline Patients & \multicolumn{5}{c}{ Ranked Viral loads } \\
\hline Treatment-Months: & 0 & 1 & 2 & 3 & 4 & 5 \\
\hline 1 & 16 & 17 & 18 & 15 & 14 & 13 \\
2 & 12 & 11 & 9 & 7 & 10 & 8 \\
3 & 2 & 6 & 5 & 4 & 3 & 1 \\
Mean & $10 \pm 7.21^{\mathrm{c}}$ & $11.3 \pm 5.51^{\mathrm{d}}$ & $10.67 \pm 6.81^{\mathrm{c}} 8.67 \pm 5.68^{\mathrm{b}}$ & $9 \pm 5.57^{\mathrm{b}}$ & $7.33 \pm 6.03^{\mathrm{a}}$
\end{tabular}

Table 2. Monthly viral load reduction-rates (\%) in HIV/AIDS Patients being treated with the Nigerian Antivirt ${ }^{\circledR}$.

\begin{tabular}{cc}
\hline MONTHS & Reduction (\%) \\
\hline 0 & 0.00 \\
1 & -41.03 \\
2 & -38.22 \\
3 & 23.98 \\
4 & 31.76 \\
5 & 64.12 \\
\hline
\end{tabular}


Table 3. Monthly viral loads of HIV/AIDS patients being treated with the Nigerian Antivirt $^{\circledR}$.

\begin{tabular}{cccccc}
\hline $\mathbf{0}$ & $\mathbf{1}$ & $\mathbf{2}$ & $\mathbf{3}$ & $\mathbf{4}$ & $\mathbf{5}$ \\
\hline $1,810,000$ & $4,260,000$ & $4,290,000$ & $1,720,000$ & $1,130,000$ & 916,000 \\
438,000 & 176,000 & 142,000 & 103,000 & 156,000 & 135,000 \\
3450 & 5090 & 5010 & 3780 & 3680 & 904 \\
\hline
\end{tabular}

month of the trial supports the theory that the medicine unmasks intracellular infections. If the medicine was not effective such that HIV continued to multiply the increase would not have been by as much as $41.03 \%$ in a month. Subsequent and continuous reductions in the viral loads confirm that the initial increase was due to unmasking of infections and not due to viral multiplication. Abnormal cells including the "sanctuary cells" have negative electrical charges [12] while Nanoparticles of molecules of AMS have both positively charged ends and negatively charged ends [6]. The Antivirt ${ }^{\circledR}$ uses positive ends of its molecular Nanoparticles to bond to HIV-infected cells including the "sanctuary cells".

AMS has been in use (for many years) to aid disintegration of drug-formulations when swallowed [6]. So, the Antivirt ${ }^{\circledR}$ may have disintegrated infected cells to unmask intra cellular infections so that the test detected more HIV-loads. Since AMS-Nanoparticles are only $0.96 \mathrm{~nm}$ thick which means they are over hundred times smaller than smallest HIV $(110 \mathrm{~nm})$ [13], the Antivirt ${ }^{\circledR}$ would reach all HIV-infected cells, including the "sanctuary cells" to destroy them and mop the virus.

First step in drug-development is to test the candidate against the pathogen, in vitro. In vitro study of the Antivirt ${ }^{\circledR}$, for antiretroviral efficacy was on plasma samples, confirmed positive for HIV antibodies, by solid phase ELISA. One of the plasma samples gave HIV titer of 32 initially, but when treated with the Antivirt $^{\circledR}$, its HIV titer increased to $\geq 4096$. Second treatment of that particular plasma with the Antivirt ${ }^{\circledR}$ reduced its HIV titer from $\geq 4096$ to 16 ( $\geq 99.60 \%$ reduction). Also, a plasma that tested positive to HIV antibody by ELISA, was initially negative for the virus but when it was treated with the Antivirt ${ }^{\circledR}$, it tested positive for the virus. HIV titers of five other samples, also increased $(P=0.009)$ from a mean of $4.00 \pm 1.63$ to $14.00 \pm 2.00$ when treated with the Antivirt ${ }^{\circledR}$ once. When treatment with the Antivirt ${ }^{\circledR}$ was repeated, mean of the plasma-HIV titers reduced significantly $(\mathrm{P}=0.024)$ from $14.00 \pm 2.00$ to $6.50 \pm 1.50$ [14]. The initial increase in viral loads and subsequent reductions reported by NIMR in this clinical trial is exact repeat of results of that in vitro study.

Also, in an earlier clinical trial [15], viral loads of four patients increased ( $\mathrm{P}=$ $0.006)$ from $498.50 \pm 33.37$ to $1,072.50 \pm 184.55(115.29 \%)$ after treatment for a mean-duration of $3.75 \pm 2.06$ weeks and then reduced $(\mathrm{P}=0.040)$ to $407.33 \pm$ $297.27(18.29 \%)$ when the treatment-duration was increased to $6.67 \pm 2.31$ weeks. For four other patients whose treatment-duration was $12.00 \pm 2.83$ weeks, the rate of viral load-reduction improved $(\mathrm{P}=0.045)$ to $98.68 \%(24,250.00 \pm$ 
$15,939.34$ to $321.00 \pm 229.38)$.

With ten other HIV/AIDS patients earlier treated with the Antivirt ${ }^{\circledR}$ [16], pre-treatment mean-CD4 of male patients $(483.67 \pm 93.01)$ was less than $502.43 \pm 82.73$ of the females though the two means were not significantly different $(\mathrm{P}=0.88)$ but proliferation of CD4 T-lymphocytes $(3696.67 / \mathrm{ml})$ occurred in the males in Month- 8 and all 3 of them became HIV-negative. The proliferation of CD4 T-lymphocytes $(2548.43 / \mathrm{ml})$ occurred among the females in Month-9 and 2 of them tested HIV-negative. By Month-10, when higher proliferation of CD4 T-lymphocytes $(2992.80 / \mathrm{ml})$ occurred in the females, all of them became HIV-negative, thus confirming WHO's report [17] that as viral loads of HIV/AIDS patients are reducing, their immunity would be recovering (increasing CD4 counts).

Electrostatic attraction which is antiviral-mechanism of the Antivirt ${ }^{\circledR}$ is a physical effect. So, it does not have adverse effects on animal-cells. Also, Aluminum silicate and Magnesium silicate which were used for the reaction that produced the Antivirt ${ }^{\circledR}$ are safe medicines that are already approved for use by regulatory agencies in many countries (including by NAFDAC in Nigeria). Therefore, the new medicine is safe for prolonged medication as confirmed by result of the toxicological test by NIMR. Termination of HIV infection to produce cure of HIV/AIDS is only a matter of time if the treatment continues.

Since the Antivirt ${ }^{\circledR}$ has been able to reduce infection of HIV, an RNA virus (positively charged), by as much as $64.12 \%$ in five months, despite the severe immune-deficiency associated with HIV-infections, the medicine may terminate infections of Covid-19 virus (another RNA virus which is not associated with severe immune-deficiency) in a much shorter treatment-duration.

Difference in the viral load reduction-rates between first month of the trial and second month was only $2.81 \%$ but the difference between the second month and the third month increased as much as $62.20 \%$. In the second month, both unmasking of intracellular infections and mopping of extracellular viruses may have been going on at same time whereas by the third month, unmasking may have been completed so that only viral-mopping took place.

Decrease of the reduction-rate between the third month $(62.20 \%)$ and the fourth month $(7.78 \%)$ is also revealing. By the third month, HIV-loads in organs/tissues of the patients were still very high. So chances of the Antivirt $^{\circledR}$-Nanoparticles to contact HIV particles were very high whereas by the fourth month, number of HIV particles had reduced such that many Antivirt $^{\circledR}$-Nanoparticles may have passed through their organs/tissues without contacting HIV. This observation also supports the theory of physical contact between the medicine and electrically charged pathogens as mechanism for its actions.

By the fifth month, the difference in reduction-rate started increasing again (from $7.78 \%$ to $32.36 \%$ ). The increase suggests that immunity of the patients may have normalized. WHO, reported that there is inverse relationship between 
viral loads and CD4-lymphocyte counts (immunity) in HIV/AIDS patients [17]. Since viral loads of the patients have reduced, by as much as $64.12 \%$, their immunity may have normalized (CD4 $\geq 500$ ). That their clinical state remained stable, also suggests that effect of HIV-infection (immune deficiency) has reduced. Synergy between normalized immunity and viral-mopping mechanism of the medicine would hasten recovery.

\section{Authors' Contributions}

The authors collaborated for the research. Authors BLS, AD, OOA and EH verified safety and antiretroviral efficacy of the Antivirt ${ }^{\circledR}$. Author, MCOE wrote the Research proposal and drafted the manuscript while Authors, FIOO, MES, IJO, EK, NUN, MIU and CAA analyzed the data and processed the manuscript for publication. All the authors read the draft-manuscript.

\section{Conflicts of Interest}

The authors declare no conflicts of interest regarding the publication of this paper.

\section{References}

[1] Ezeibe, M.C.O. and Ogbonna, I.J. (2015) Acquired Immune Deficiency Syndrome in Man and Animals-A Review. World Journal of Aids, 5, 50-57. https://doi.org/10.4236/wja.2015.51006

[2] HIV/AIDS: Where Did HIV Come from? http://www.infoplease.com/cig/dangerous-diseases-epidemics/hiv-origins.html\#ixzz 30cwXMs00

[3] Brooks, G.F. (1998) Medical Microbiology. 21st Edition, McGraw Hill, San Francisco.

[4] Chen, B.D., Le, W.J., Wang, Y.L., Li, Z.Q., Wang, D., Ren, L., Lin, L., Cui, S.B., Hu,J.J., Hu, Y.H., Yang, P.Y., Ewing, R.C., Shi, D.L. and Cui, Z. (2016) Targeting Negative Surface Charges of Cancer Cells by Multifunctional Nanoprobes. Theranostics, 6, 1887-1898. https://doi.org/10.7150/thno.16358

[5] Cristina, E., Ivan, P. and Kevin, R. (2007) Nanomaterials and Nanoparticles: Sources and Toxicity. Biointerphases, 2, MR17-MR71. https://doi.org/10.1116/1.2815690

[6] Vanderbilt, R.T. (2012) Veegum-The Versatile Ingredient for Pharmaceutical Formulations. Inc. Technical Literature.

[7] Suni, L., Hiroaki, H., Megumi, M., Hidenori, M., Aoko, K.T., Ying, C., Kozo, U., Masayasu, K., Yasumitsu, N. and Takemi, O.T. (2014) Immunostimulation by Silica Particles and the Development of Autoimmune Dysregulation. InTechOpen, London.

[8] Ezeibe, M.C.O. (2012) Medicinal Synthetic Aluminum-Magnesium Silicate (Nanoparticles)-Antiviral Agent and Adjuvant to Chemotherapeutics. Federal Republic of Nigeria Patents and Designs Ref No. NG/P/2012/639.

[9] Murray, K.R. (2000) Harpers Biochemistry. McGraw Hill, New York.

[10] Ezeibe, M.C.O. and Ogbonna, I.J. (2016) Use of the Medicinal Synthetic Aluminum 
Magnesium Silicate to Enhance Efficacy of Antimicrobials, for Prevention and Treatment of Resistant Infections. 2nd International Conference and Exhibition on Pharmacology and Ethnopharmacology, Chicago, 2-4 May 2016.

[11] Ezeibe, M.C.O. (2017) Antivirt'. Broad Spectrum Antiviral Medicine and Antiretroviral Medicine. Federal Republic of Nigeria Patents and Designs Ref No: NG/P/2017/2418.

[12] Steve Haltiwanger MD., CCN. (2011) The Electrical Properties of Cancer Cells. http://www.royalrife.com/haltiwanger1

[13] Gentile, M., Adrian, T., Scheidler, A., Ewald, M., Dianzani, F., Pauli, G. and Gelderblon, H.R. (1994) Determination of the Size of HIV Using Adenovirus Type 2 as an Internal Length Marker. Journal of Virological Methods, 4, 43-52. https://doi.org/10.1016/0166-0934(94)90087-6

[14] Ezeibe, M.C.O., Ngene, A.A., Kalu, I.K., Ezeh, I.O., Mbuko, I.J., Ekwuruke, J.O., Anene, I., Amechi, B., Olowoniyi, P. and Ifekwe, I.F. (2014) Assessment of Antiretroviral Effects of a Synthetic Aluminum-Magnesium Silicate. British Journal of Medicine and Medical Research, 4, 1672-1679.

[15] Ezeibe, M.C.O. and Ogbonna, I.J. (2016) Medicinal Synthetic Aluminum-Magnesium Silicate $\left\{\mathrm{Al}_{4}\left(\mathrm{SiO}_{4}\right)_{3}+3 \mathrm{Mg}_{2} \mathrm{SiO}_{4} \rightarrow 2 \mathrm{Al}_{2} \mathrm{Mg}_{3}\left(\mathrm{SiO}_{4}\right)_{3}\right\}$-A Highly Active Anti-Retroviral Medicine. World Journal of Aids, 6, 42-46.

[16] Ezeibe, M.C.O., Aleeyu, D., Aneke, N.K., Obarezi, T.N., Ogbonna, I.J., Kalu, E. and Njoku, N.U. (2016) HIV/AIDS Recovery Rates in Male and Female Patients, Treated with Medicinal Synthetic Aluminum-Magnesium Silicate. British Journal of Medicine and Medical Research, 18, 1-7. https://doi.org/10.9734/BJMMR/2016/29018

[17] World Health Organization (2007) Laboratory Guidelines for Enumerating CD4 T Lymphocytes in the Context of HIV/AIDS. World Health Organization Regional Office for South-East Asia, New Delhi. 